Olekshij P. V. Dynamics of changes in nonspecific resistance of guinea pigs under conditions of formation of experimental periodontitis and immobilization stress. Journal of Education, Health and Sport. 2021;11(11):67-72. eISSN 2391-8306. DOI http://dx.doi.org/10.12775/JEHS.2021.11.11.005

https://apcz.umk.pl/JEHS/article/view/JEHS.2021.11.11.005

https://zenodo.org/record/5668663

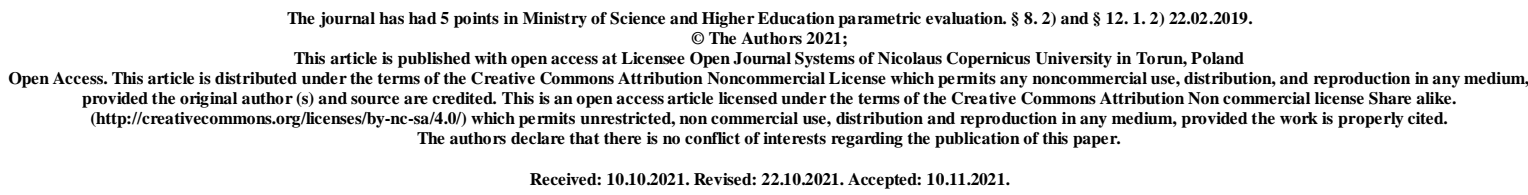

UDC: 616.314.18-002.4:612.176:616.155.3:615.015.8]-092.9

\title{
Dynamics of changes in nonspecific resistance of guinea pigs under conditions of formation of experimental periodontitis and immobilization stress
}

\section{P. V. Olekshij}

\section{Lviv Medical Institute}

\begin{abstract}
The aim of our study was to determine the phagocytic activity of leukocytes and nitrosine tetrazolium test (NST - test) in the dynamics of experimental periodontitis (EP) and immobilization stress (IS). It is established in the work that the indicators studied by us, namely phagocytic number, phagocytic index and NST - test increase on the $3^{\text {rd }}, 5^{\text {th }}$ and $15^{\text {th }}$ days of our experiment. The above tests have a high diagnostic value and allow to characterize the degree of activity of the inflammatory process and determine the participation of individual parts of the body's defense mechanisms. The obtained results make it possible to express the opinion that polymorphonuclear leukocytes take an active part in the formation of EP and IS, as well as indicate the stimulation of metabolic processes in leukocytes.
\end{abstract}

Key words: periodontitis; stress; polymorhonuclear leucocytes; nonspecific resistance. 


\title{
Динаміка змін неспецифічної резистентності морських свинок за умов формування експериментального парадонтиту та іммобілізаційного стресу
}

\author{
П. В. Олекшій
}

\section{Львівський медичний інститут}

Метою нашого дослідження було вивчення фагоцитарної активності лейкоцитів та тесту нітросинього тетразолію (НСТ - тест) в динаміці розвитку експериментального пародонтиту (ЕП) та іммобілізаційного стресу (IC). У роботі встановлено, що досліджувані нами показники, а саме фагоцитарне число, фагоцитарний індекс та НСТ - тест зростають на 3-ю, 5-у та 15-у доби нашого експерименту. Вище досліджувані тести мають високу діагностичну цінність і дозволяють характеризувати ступінь активності запального процесу та визначити участь окремих ланок механізмів захисту організму. Одержані результати дають можливість висловити думку про те, що поліморфно-ядерні лейкоцити приймають активну участь у формуванні ЕП та IC, a також свідчать про стимуляцію метаболічних процесів у лейкоцитах.

Ключові слова: пародонти; стрес; поліморфно-ядерні лейкоцити; неспецифічна резистентність.

Динамика изменений неспецифической резистентности морских свинок в условиях формирования экспериментального пародонтита и иммобилизационного стресса

\section{П. В. Олекший}

\section{Львовский медицинский институт}

Целью нашего исследования было изучение фагоцитарной активности лейкоцитов и теста нитросинего тетразолия (НСТ - тест) в динамике развития экспериментального пародонтита (ЭП) и иммобилизационного стресса (ИС). В работе установлено, что исследуемые нами показатели, а именно фагоцитарное число, фагоцитарный индекс и НСТ - тест увеличиваются на 3-е, 5-е и 15-е сутки нашего 
эксперимента. Выше исследуемые тесты имеют высокую диагностическую ценность и позволяют характеризовать степень активности воспалительного процесса и определить участие отдельных звеньев механизмов защиты организма. Полученные результаты дают возможность выразить мнение о том, что полиморфно-ядерные лейкоциты принимают активное участие в формировании ЭП и ИС, а также свидетельствуют о стимуляции метаболических процессов в лейкоцитах.

Ключевые слова: пародонтит; стресс; полиморфно-ядерные лейкоциты; неспецифическая резистентность.

Introduction. To date, the most pressing problem of dentistry is periodontal disease, especially generalized periodontitis. Their prevalence reaches among people aged 35-44 years and older 92-98\% [5] and increases among young people (19-24 years) to 30\%, and 25-30 years - more than $60 \%$ [8]. The development of generalized periodontitis occurs against the background of complex disorders of homeostatic balance of the body and is accompanied by its intoxication and sensitization, reduced anti-infective protection, the development of complications. Non-specific reactivity factors play an important role in the body's antiinfective protection [4].

Polymorphonuclear leukocytes are one of the leading link in this system. Together with macrophages, they are involved in the absorption and disintegration of antigens, which produce a number of antiviral and bactericidal substances, mediators of inflammation. It is established that the violation of nonspecific resistance in patients is one of the significant reasons for the formation of a chronic course of a disease [7].

It is known from the literature that the combined pathology leads to significant changes in physiological processes in the body, reduces adaptive reserves, affects the course of the underlying disease, complicates diagnosis and is more difficult to treat [6]. We chose periodontitis and stress as a pathophysiological model for comorbid pathology.

Thus, the aim of our study was to study the phagocytic activity of leukocytes (PhLA) and nitrosin tetrazolium test (NST-test) in the dynamics of experimental periodontitis (EP) and immobilization stress (IS).

Material and methods of research. Experimental studies were performed on 40 guinea pigs (males), weighing $0.18-0.21 \mathrm{~kg}$, kept on the standard diet of the vivarium of Danylo Halytsky Lviv National Medical University. Guinea pigs were divided into four groups (10 in each): the first - intact animals - control; the second (experimental) group - 
animals with experimental periodontitis and immobilization stress ( $3^{\text {rd }}$ day), the third group included guinea pigs with EP and IS on the $5^{\text {th }}$ day of the combined model process, to IV animals with EP and IS on the $15^{\text {th }}$ day).

Experimental periodontitis was modeled by the method of ZR Jogan (1983) [3]. Immobilization stress was reproduced by the method of PD Horizontov (1996) [2]. We selected fixed days $\left(3^{\text {rd }}, 5^{\text {th }}\right.$ and $\left.15^{\text {th }}\right)$ for studies that corresponded to the classic stages of acute inflammation. All experiments on laboratory animals carried out with following the European Convention for the protection of vertebrate animals used for experimental and other scientific purposes (Strasbourg, 1986), Council Directive 2010/63 / EU, the Law of Ukraine 3447- IV "protection animals from the cruelty," the general ethics of animal experimentation adopted by the first national Congress on bioethics in Ukraine (2001).

We evaluated nonspecific resistance of the organism by studying phagocytic number $(\mathrm{PhN})$ [1], phagocytic index $(\mathrm{PhI})$ [1] and NST test [1] in peripheral blood of guinea pigs at certain stages of development of the experimental comorbid model. Digital results were processed by statistical method using Student's criterion.

Research results and discussion. Studying $\mathrm{PhI}$ in peripheral blood of guinea pigs at EP and IS we observe the following picture: the phagocytic index, as well as $\mathrm{PhN}$ on the $3^{\text {rd }}$ day increases by 55,5\% (p $\geq 0,05)$ and $69,0 \%(p \geq 0,05))$, respectively, at the level of control values ( $\mathrm{p} \geq 0.05$ ). Further, $\mathrm{PhI}$ increases even more, namely on the $5^{\text {th }}$ and $15^{\text {th }}$ day by $61.1 \%$ and $70.2 \%$, respectively, compared with the control $(\mathrm{p} \leq 0.05)$. Similar, only even more significant changes occur with the phagocytic number: an increase of $85.7 \%$ and $90.4 \%$, respectively, on the $5^{\text {th }}$ and $15^{\text {th }}$ days of the experiment against group I animals $(\mathrm{p} \leq 0.05)$. Thus, summing up the change in PhAL in guinea pigs in EP and IS, we see the progression of leukocyte activity under these conditions.

We also studied the NST test, which is recognized as one of the most objective criteria for assessing the functional status of polymorphonuclear leukocytes in the peripheral blood. The results of the study showed that the indicators of this test increased during all the days studied by us: on the $3^{\text {rd }}, 5^{\text {th }}$ and $15^{\text {th }}$ days, respectively, an increase of $66.1 \%, 74.5 \%$ and $83.0 \%$ compared with the control group animals $(\mathrm{p} \leq 0.05)$, which indicates possible stimulation by the nonspecific resistance.

The dynamics of the level of non-specific resistance in the blood of guinea pigs in EP and IS are presented in table 1. 
Table 1. The level of PhAL and NST test in the blood of guinea pigs in EP and IS. (M $\pm \mathrm{m}, \mathrm{n}=40)$

\begin{tabular}{|c|c|c|c|c|c|}
\hline \multirow{2}{*}{$\begin{array}{c}\text { Form of } \\
\text { experiment }\end{array}$} & $\begin{array}{c}\text { Duration of the } \\
\text { disease in days }\end{array}$ & $\begin{array}{c}\text { Number of } \\
\text { animals }\end{array}$ & PhI,\% & PhN,\% & NST test, \% \\
\hline $\begin{array}{l}\text { Intact animals. } \\
\text { Control }\end{array}$ & 10 & $63,5 \pm 4,1$ & $4,2 \pm 0,7$ & $5,9 \pm 1,1$ \\
\hline \multirow{2}{*}{$\begin{array}{l}\text { Guinea pigs } \\
\text { with EP and IS }\end{array}$} & 3 & 10 & $98,8 \pm 5,1$ & $7,1 \pm 0,7$ & $9,8 \pm 1,7$ \\
\cline { 2 - 6 } & 15 & 10 & $102,3 \pm 5,2$ & $7,8 \pm 0,7$ & $10,3 \pm 1,8$ \\
\hline
\end{tabular}

Conclusions. The above research tests (PhAL and NST) have a high diagnostic value and allow to characterize the degree of activity of the inflammatory process and to determine the participation of individual parts of the body's defense mechanisms. The obtained results give an opportunity to express the opinion that polymorphonuclear leukocytes take an active part in the formation of EP and IS, as well as indicate the stimulation of metabolic processes in leukocytes.

\section{References}

1. Gembitsky EV. Assessment of the immune status of the organism in medical establishments of the Soviet army and navy: Methodical manual. - Central Military Medical Directorate of the USSR Defense Ministry.1987. 114. (in Russian)

2. Gorizontov PD, Belousov OI, Fedotov MI . Stress i systema krovi. M .: Medicine, 1983.p.338. (in Russian)

3. Jogan ZR Clinico-experimentalne obosnovanie usovershenstvovania orthopedichnyx metodiv pry complexnomu likuvanni chvorob parodonta. Author's ref. Dis. Candidate of Medical Sciences, Kyiv, 1996. p.18. (in Ukrainian)

4. Kononova, O. V. (2018). Eksperymentalne obhruntuvannia zastosuvannia adrenoblokatoriv. Sovremennaia stomatolohyia, 2: 86-89 (in Ukrainian).

5. Kononova, O.V. (2018). Patohistolohichne doslidzhennia vplyvu kompleksu adrenoblokatoriv na reheneratsiiu kistky shchelepy. Sovremennaia stomatolohyia. 3: 36-38 (in Ukrainian).

6. Arunachalam M, Pulikkotil SJ, Sonia N. Platelet Rich Fibrin in Periodontal Regeneration. The Open Denistry Journal. 2016. (in English). 
7. Dixit S, Doshi Y, Shah MU, Dabholkar CS. Management of chronic generalized periodontitis using diode laser. J Indian Soc Periodontol 2016;20:88- 90. (in English).

8. Newman, M., Takei, H., Klokkevold, P., \& Carranza, F. (2018). Newman and Carranza's Clinical Periodontology, 13th Edition. St. Louis: Saunders, 944 (in English). 